研究資料

\title{
運動部活動における目標設定，勝利志向性，意見の反映度の実態 並びにそれらが生徒の満足度に及ぼす影響
}

\author{
深見英一郎1)＼cjkstart岡澤 祥訓2)
}

Eiichiro Fukami ${ }^{1}$ and Yoshinori Okazawa ${ }^{2}$ : The influence of goal-setting, desire to win, and individual opinion on the satisfaction of students with athletic clubs. Japan J. Phys. Educ. Hlth. Sport Sci. 61: 781796, December, 2016

\begin{abstract}
The purpose of this study was to analyze consciousness with regard to team/individual goalsetting, desire to win, and individual opinion in relation to the satisfaction of students with athletic clubs.

We conducted a questionnaire survey of athletic clubs to investigate 3 issues related to team goalsetting: a) whether the goals were set or not, b) who was responsible for deciding the goals, and c) whether the goals were shared or not. We also investigated 3 issues related to students' personal goalsetting: a) whether the goals were set or not, b) whether a concrete plan for goal achievement was formulated or not, and c) whether an effort was made to accomplish these aims. We also investigated students' desire to win, the degree of reflection of individual student opinion, and satisfaction gained from applying individual aims using a survey of athletic club activity devised by the Japanese Ministry of Education (1997).
\end{abstract}

The study involved 4,104 students at 292 athletic clubs in 29 junior high schools, and 3,944 students at 249 athletic clubs in 23 high schools (8,048 students in total). The response rate was $69.9 \%$.

The main results were as follows:

1) Most of the students had their own personal goals, made concrete plans for achieving them, and made an effort to accomplish their aims. Also, team goals were set, and these were decided and shared by all students.

2) Most of the students recognized that their teams were victory-oriented. In addition, they considered that coaches were positively responsive to students' opinions during practice and games.

3) Therefore, most students had a high level of satisfaction with their athletic clubs.

Key words : questionnaire survey, students' consciousness, personal goals, team goals キーワード : 質問紙調査, 生徒の意識, 個人目標, チーム目標

\section{1. 目的}

運動部活動は, 学習指導要領にその意義と留意 点等が記載され（文部科学省, 2012), 学校教育
活動の一環として大きな役割を果たしている。そ こでは多くの教師が授業や生徒指導を遂行する傍 ら, 顧問教師となって運動部活動の指導と運営に 携わっている. その結果, ほぼすべての中学・高 等学校に運動部活動が設置され, 全教師の半分以
1) 早稲田大学スポーツ科学学術院

干359-1192 埼玉県所沢市三ヶ島 2-579-15

2) 大阪体育大学教育学部

干590-0496 大阪府泉南郡熊取町朝代台 1-1 連絡先 深見英一郎
1. Faculty of Sport Science, Waseda University 2-579-15 Mikajima, Tokorozawa, Saitama 359-1192

2. School of Education, Osaka University of Health and Sport Sciences

1-1 Asashirodai, Kumatori-cho, Sennan-gun Osaka 590-0496

Corresponding author eiichiro@waseda.jp 
上が顧問に就き（文部科学省，2002），6 割以上 の中学生と 4 割以上の高校生が運動部活動に加 入している状況にある（文部科学省, 2015). 運 動部活動では, 異学年の同好の土や指導者など様 々な人間と関わり合い，その中で責任感，協調 性，思いやりの心などを身につけることが期待さ れている．また，日常的に自己選択や自己決定が 求められることで自己実現の基礎を培うことがで き，様々な体験を通して社会性や行動力などを身 につけることが期待されている（教育新聞, 2011).

文部科学省（2014）は, 運動部活動の指導の あり方について,「生徒との意見交換等を通じて ……生徒の主体性を尊重しつつ, 各活動の目標, 指導の方針を検討，設定すること」，「部活動の方 向性や各自の取組姿勢, 試合での作戦や練習にか かる事柄等について，生徒同士で主体的に筋道を 立てて話し合い」をさせることと指摘している. なぜ，運動部活動において生徒の主体性を尊重す る必要があるのか. Danish et al. (1993) は, 自 分で考えて目標を設定することが人間の行動を動 機づける力の源であると指摘している。目標設定 は，今，自分に足りないものを明確にし，努力の 方向性を明らかにすることである。一般に，ス ポーツ場面ではチームや個人の目標が掲げられ， その目標達成に向けた計画の立案や活動が遂行さ れる. 生徒は, 自分やチームの目標を設定するこ とで, 練習に取り組む意識や行動が変わり, 目標 の達成に近づくことができる，また，上手くいか ない時や望んでいた結果がなかなか出ない時でも 燃え尽きたりせず，気持ちを切り替えて工夫や努 力をすることができるのである（岡沢，2001； 上野, 2006).

それでは, 実際の運動部活動において指導者の 主導性はどの程度発揮され，生徒が自分たちで考 えたり意思決定したりする機会はどの程度保障さ れているだろうか.たとえば, 中学校の運動部指 導者の管理行動を調查した藤田・吉田（2010） は, 競技経験年数が長く, より高い競技レベルを 持つ指導者は，そうでない指導者と比較してより 有意に積極的な管理行動を行っていると指摘して
いる．また，高校の陸上部員を対象とした指導者 の主導性に関する調査（佐藤・長堂, 1995 ; 鶴 山，2010）では, 男子や上級生は自分たちで主 体的に活動することを望む反面, 女子や下級生は 指導者の強い主導性を期待する傾向がみられたと いう. さらに, 中学校では指導者が独断で練習入 ニューや試合メンバーを決める傾向がみられ，ま た生徒も自分たちで決められず指導者に決めても らいたいと考えているとの報告（丸山，2013） もみられる.これらの結果から, 運動部活動の指 導場面に打いて指導者が強いリーダーシップを発 揮することで生徒の主体性が尊重されないケース や, 生徒自身も指導者の主導性に依存する傾向が みられた。しかしながら, 運動部活動における指 導者の主導性の発揮のしかたに着目した研究自体 が少なく（倉藤ほか，2011；桑野ほか，2014）， 対象とした競技種目にも偏りがみられ, 生徒の発 達段階に応じた指導のあり方については十分に検 討できていないことが明らかになった．このこと に関して, 中澤（2015）は運動部活動の成立要 件が生徒の意思よりも学校と教師の支援に大きく 左右されるため, 運動部活動における生徒の意識 や行動，また中学生と高校生の取り組み方の違い について十分に検討がなされていないと指摘して いる. 今日では，顧問の専門性や外部指導者の問 題, また保護者対応や土日勤務などの問題（朝日 新聞，2016a，2016b ; 佐藤，2013 ; 友添，2013) が山積する中で, 生徒の自治活動としての運動部 活動を実践している例もある. 制野（2013）は 自身が受け持つ中学校野球部において, 練習計 画・内容の決定だけでなく試合においても新たに 試したいことやオーダーの組み方, ゲーム中の采 配まで生徒に交代で担当させている. 生徒には徹 底的に考えることを求め, 顧問はより高い次元の 生徒の自治が発揮されるように，そのプロセスを 整えるコーディネーターの役割に徹するという。 これまで日本のスポーツ指導では, どのレベルや 年代で何回勝たせたかが指導者の力量として評価 される傾向がみられたが，生徒は負けた結果から も多くのことを学び教訓を得ており, 必ずしも勝 たせた指導者だけがその生徒を勝利に導いたとは 
言えないのである（勝田, 2000). 伊藤 (2013) は, Jean and Wade (2009) による優れたコーチ ングの考察結果をふまえて, 次のように指摘して いる．優れたコーチングの条件とは，スキルを向 上させたり試合で勝利に導くといった(1)有能さ (Competence), それによって選手に(2)自信を与 え (Confidence), 選手がパフォーマンスを最大 限発揮できるように(3)周囲の人間関係を構築し (Connection)，さらに(4)人間的な成長を促す (Character) といった 4 つの $4 \mathrm{Cs}$ が重要であり, 選手が収めた競技成績の結果のみで判断してはな らないと指摘している. 西島 $(2006,2013)$ は, 「先生方は『大人は完璧で, 生徒は未熟で指導す べき』とか『生徒たちに自治能力が育っていない から任せられない』と思っていないか. 試しに生 徒たちに運動部活動の運営を任せたら,きっと生 徒たちは自分たちでもっとできるように成長でき るはず」と指摘している.

それでは, 今日の運動部活動において, 実際に はどのくらいの中・高校生が, 自分たちでチーム の目標を設定し, 共有できているか. 運動部活動 では, 様々な目的や目標を持った異学年の生徒が 一堂に会して, 年間を通じて非常に長い時間を チームで活動する，そのため，たとえ個人の目標 はばらばらでも, チームの目標がチーム全員で統 一され，共有されることが望なしい。また，個人 の目標についても，個人/集団種目にかかわら ず，すべての生徒がチームの目標とは別に，個人 の目標をもち, その達成に向けて計画を立てて取 り組んでいることが望ましいと考えられる.さら に, チームが目指す方向性について, 文部科学省 （2014）は，「……勝つことのみを目指すことの ないよう, 生徒が生涯にわたってスポーツに親し む基礎を育むこと, 発達の段階に応じた心身の成 長を促す」ことと指摘している，このように勝つ ことを目指すことは重要であるが，それ以上に生 涯スポーツの基礎を育成することを重視してい る、果たして生徒は運動部活動において, 勝利す ることをどの程度, 重視して取り組んでいるの か. 加えて, 練習や試合に扔いて生徒の意見はど の程度反映されているのか. 先述したように, 練
習や試合に関わる事項については生徒同士で主体 的に話し合わせ，できるだけ彼らの意見を取り入 れ, 生徒の主体性を尊重することが望をしいと考 えられる.

また,これらの検討課題に関して生徒の発達段 階の違いや個人/集団種目の違いによって, その 実態にどのような差異がみられるかについても未 だ明らかにされていない。一般的に考えれば，中 学生と高校生では, 生徒の人間的な成熟度が異な るため, 部のあり方や方針を決定したり協同的な 活動を遂行したりする能力は, 高校生の方が高い のではないかと予想される. そのため, 中学生で は指導者がある程度, 主導的にチームの目標や練 習内容を設定して取り組ませている一方で, 高校 生では自分たちで目標や練習内容を考えさせ, 生 徒の主体的活動を一定程度保障していると考えら れる.さらに, 個人種目と集団種目では, 個人種 目の生徒の方が, 自身の明確な目標を立て達成に 向けて計画的に取り組んでいる割合が高い一方 で，集団種目の生徒の方が，自分たちでチームの 目標を決定し, チーム全員で共有している割合が 高いと考えられる.

そこで本研究では, チーム/個人の目標設定の しかた, チームの勝利志向性, 生徒の意見の反映 度それぞれの実態を明らかにすること，またそれ らの実態と生徒の満足度との関係について分析し ようとした。具体的には, (1)チームの目標に関わ って, 誰が決定し, チームでどの程度共有できて いるか. (2)個人の目標に関わって，どのくらいの 生徒が目標を立てて, 目標達成に向けて実際に行 動できているか. (3)所属する運動部は勝つことを どの程度, 重視しているか.(4)練習や試合におい て, 生徒の意見はどの程度, 反映されているか, についてそれぞれ分析する。 また，それらが生徒 の発達段階及び個人/集団種目の違いによって特 徵がみられるかを明らかにする。ささらに, それら の実態と運動部活動に対する生徒の満足度との関 係を分析することによって, 生徒にとって望まし い運動部活動のあり方について明らかにしようと した. 


\section{2. 方 法}

\section{1）調査の対象と実施時期}

表 1 は, 対象とした中学校及び高等学校の運 動部活動の数と生徒数を示したものである. 全国 11府県の中学校29校, 高等学校23校の運動部, それぞれ中学校292部（個人種目 164 部, 集団種 目128部）とその生徒4104名（個人種目2043名, 集団種目 2061 名)，高等学校249部（個人種目 136 部，集団種目113部）とその生徒3944名（個人種 目1618名, 集団種目2326名), 合計541部8048名 を対象とした注1)。学校種別に運動種目別生徒 数の差があるかについて連関性を見るために $\chi^{2}$ 検定を行ったところ有意であった（ $\chi^{2}(1)=$

表 1 対象とした中学校及び高等学校の運動部活動の 数と生徒数

\begin{tabular}{c|c|c|c|c|c|c}
\hline \multirow{2}{*}{} & \multicolumn{2}{|c|}{ 中学校 } & \multicolumn{2}{c|}{ 高等学校 } & \multicolumn{2}{c}{ 全 体 } \\
\cline { 2 - 7 } & 部 & 生徒 & 部 & 生徒 & 部 & 生徒 \\
\hline 個人種目 & 164 & 2043 & 136 & 1618 & 300 & 3661 \\
\hline 集団種目 & 128 & 2061 & 113 & 2326 & 241 & 4387 \\
\hline 計 & 292 & 4104 & 249 & 3944 & 541 & 8048 \\
\hline
\end{tabular}

$110.005, \mathrm{p}<.001, \phi=.117)$. この結果と残差か ら, 高校生は集団種目が多いと解釈された。本調 查は， 2014 年 9 月一 2014 年 12 月にかけて行った.

\section{2）調査の手続き}

アンケート調査を実施するにあたり，事前に各 学校の学校長及び保健体育主任にアンケート内容 を確認してもらい，許可が得られた学校に対して の久調査用紙を送付した。全国11府県の中学校 35 校，高等学校 25 校に，それぞれ6040通，5480 通，計11520通のアンケート用紙を送付した結 果, 中学校 29 校, 高等学校 23 校から生徒 8048 名 （回収率69.9\%）の回答が得られた。調査は，各 運動部の指導者を通じて生徒に回答してもらっ た注2).

\section{3） 運動部活動への取り組みに関する調査票}

表 2 は, 運動部活動への取り組みに関する調 查票を示したものである。この調査票は，(1)チー ムの目標設定，(2)個人の目標設定，(3)チームの勝 利志向性, (4)生徒の意見の反映度, (5)生徒の満足 度の 5 観点について調査するものである.

（1）チームの目標設定は，a）目標の有無，b) 決定者，c）共有状況について調査した。 また，

表 2 運動部活動への取り組みに関する調査票

1）所属している運動部にはチームが目指す目標はありますか（ある/ない）

1-1）「チームの目標がある」と回答した方へ。その目標は誰が決めましたか 指導者/指導者と一部の生徒（主将, 副主将など)/指導者とすべての生徒/すべての生徒

1-2）「チームの目標がある」と回答した方へ。その目標はチームで共有できているか すべての生徒が共有している/一部の生徒が共有していない/ほとんどの生徒が共有していない

2）所属している運動部において個人の目標を設定していますか（ある/ない）

2-1）「個人の目標がある」と回答した方へ。その目標達成に向けた計画はありますか 具体的な計画がある/なんとなく計画はある/計画はない

2-2）「個人の目標がある」と回答した方へ，その目標達成に向けて努力できているか 十分に努力できている/努力できている/あまり努力していない/ほとんど努力していない

3）所属している運動部は何を目指して活動していますか（勝利志向と楽しみ志向） 徹底して勝つ/ある程度勝つことを中心にしながら楽しむ/ みんなで楽しむことを中心とし，できれば勝つ/とことん楽しむ

4）所属している運動部の練習や試合に生徒の意見は反映されていると思いますか. とても反映されている/反映されている/あまり反映されていない/ほとんど反映されていない

5）運動部活動に対する満足度（部活動は楽しいか） とても楽しい/どちらかというと楽しい/どちらかというと苦しい/とても苦しい 
b) 決定者については，(1)指導者，(2)指導者と一 部の生徒（主将, 副主将など), (3)指導者とすべ ての生徒, (4)すべての生徒という4つの選択 肢，さらにc）共有状況については，(1)すべての 生徒が共有している, (2)一部の生徒が共有してい ない，(3ほとんどの生徒が共有していない，とい う3つの選択肢をそれぞれ用意した。

（2）個人の目標設定は，a）目標の有無，b) 達成計画，c)達成努力について調査した。 また， b)達成計画については，(1)具体的な計画がある, (2)なんとなく計画はある, (3)計画はない, という 3 つの選択肢, さらにc）達成努力については, (1)十分に努力できている，(2)努力できている，(3) あまり努力していない，(4)ほとんど努力していな い，という 4 つの選択肢をそれぞれ用意した.

（3）チームの勝利志向性については，a）徹底 して勝つ，b）ある程度勝つことを中心にしなが ら楽しむ，c）みんなで楽しむことを中心とし， できれば勝つ，d）とことん楽しむ，という 4 つ の選択肢を用意した.

（4）生徒の意見の反映度については，a）とて も反映されている，b）反映されている，c）あ まり反映されていない，d）ほとんど反映されて いない，という 4 つの選択肢を用意した。

（5）生徒の満足度については，a）とても楽し い，b）どちらかというと楽しい，c）どちらか というと苦しい，d）とても苦しい，という4つ の選択肢を用意した.

また, 生徒の属性として, (1)学校種（中学生/ 高校生）及び(2)運動種目（個人/集団種目）の違 いによって，上記した調査内容に差異や特徵がみ られるかを検討した。

な抢, チームの勝利志向性, 生徒の意見の反映 度, 生徒の満足度という3 つの質問内容は, 文 部省（1997）の「運動部活動の在り方に関する 調查研究報告」で使用された質問項目及び選択肢 を採用した。このうち，(5)）生徒の満足度につい ては, 文部省（1997）の調査研究報告に倣って, 「楽しい」という評価を「満足度」として捉えた. 当然, 楽しさと満足度の高さは完全に対応するも のではないが, 複数の先行研究から運動・スポー
ツに対する生徒の満足度を規定する主要因の 1 つが「楽しさ」であることが報告されていること から，文部省（1997）の評価基準をそのまま採 用した注3).

\section{4）統計解析の方法}

統計解析の手続きは IBM SPSS Statistics 20を 用いて行った。期待度数と測定值との間にどの 程度の差異が認められるかを推測するために Pearson の $\chi^{2}$ 検定及び残差分析を行った注4). た, $\chi^{2}$ 検定の結果の解釈では, 効果量として 係数及び Cramer's V を求め有意性と併せて確認 した．効果量は 0.0 - 1.0 の範囲をとり，大きさの 目安は，「ほとんど関連性はない」（ $\phi$, Cramer's $\mathrm{V}< \pm 0.2)$, 「関連性がある」( $\phi$, Cramer's V $> \pm$ $0.4)$,「強い関連性がある」( $\phi$, Cramer's V $> \pm$ 0.7）とした.さらに, 生徒の満足度が各測定項 目の割合とどのように関係しているかを記述する ためにカテゴリー回帰分析を使用した.

\section{3. 結果と考察}

\section{1）チームの目標設定}

表 3 は, チーム目標の有無, 決定者, 共有状 況に関する生徒の回答を全体の割合, 運動種目別 及び学校種別で分析したものである. その結果, チームの目標について，全体で86.7\%（6978名） の生徒が「目標がある」と回答した。 $\chi^{2}$ 検定の 結果, 運動種目別 $\left(\chi^{2}(1)=402.79, \mathrm{p}<.001, \phi=\right.$ $-.220)$, 学校種別 $\left(\chi^{2}(1)=10.09, \mathrm{p}<.01, \phi=\right.$ - .038）それぞれにおいて有意差が認められた. 効果量の值から，運動種目別にみたチーム目標の 有無間には弱い関連性がみられ, 人数の偏りが 確認された注5). 残差分析の結果, 運動種目別で は, 個人種目よりも集団種目で $(Z= \pm 20.1, p$ $<.01)$, 学校種別では中学生よりも高校生が $(Z$ $= \pm 3.2, \mathrm{p}<.01)$, それぞれ「目標がある」と回 答した割合が有意に高かった。

次に, チーム目標の決定者では,「すべての生 徒」で決定した割合が $45.3 \%$ （3162名）と最も 高く, 次いで「指導者とすべての生徒」は36.3\% 
表 3 運動種目/学校種別にみたチーム目標の有無, 決定者, 共有状況

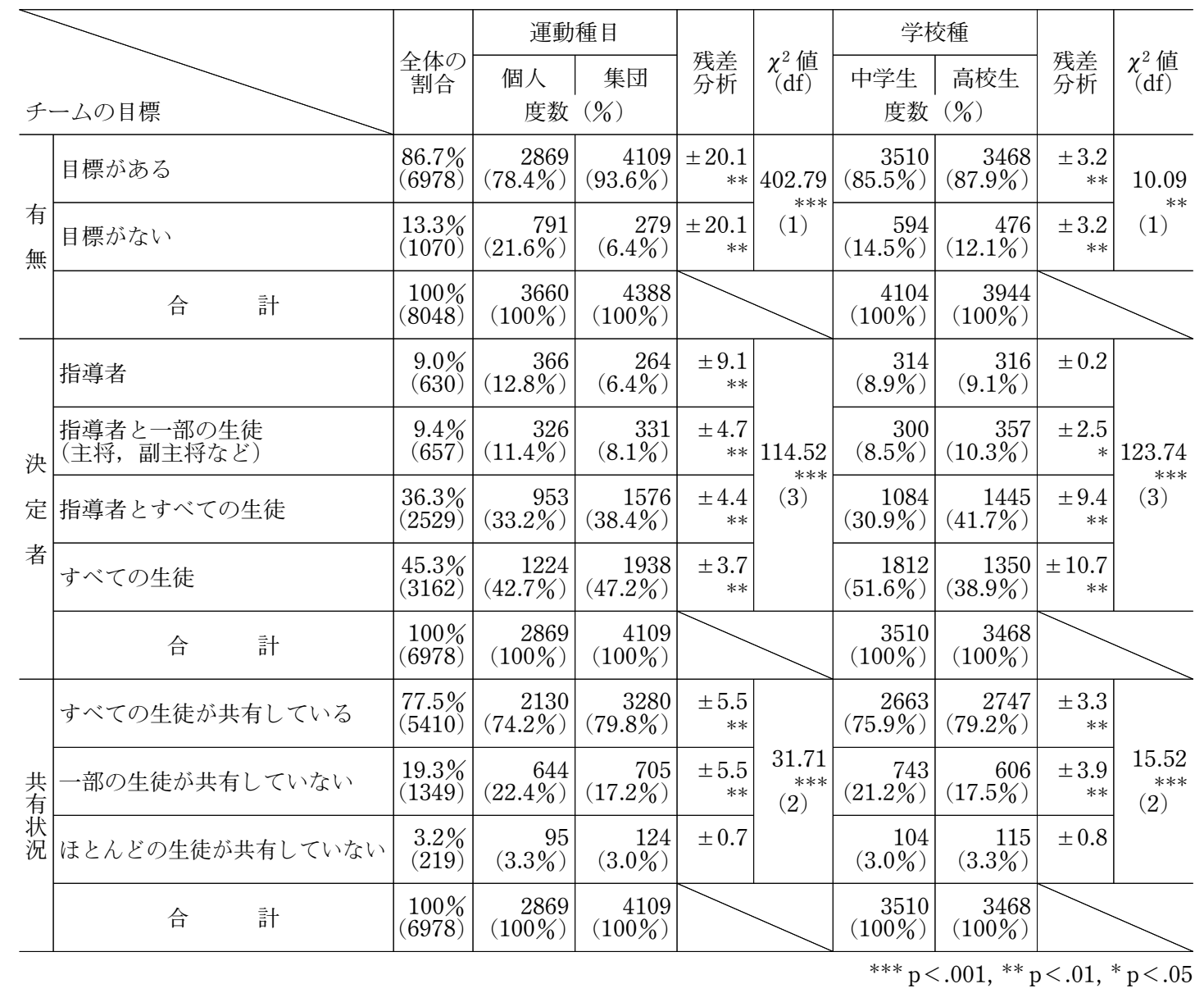

(2529名) であり, 合わせて8割以上の生徒がチー ム目標の決定にすべての生徒が関与していたと回 答した。 $\chi^{2}$ 検定の結果, 運動種目別 $\left(\chi^{2}(3)=\right.$ $114.52, \mathrm{p}<.001$, Cramer's $\mathrm{V}=.134)$, 学校種別 $\left(\chi^{2}(3)=123.74, \mathrm{p}<.001\right.$, Cramer's V=.132) そ れぞれにおいて有意差が認められた．残差分析の 結果, 運動種目別では, 集団種目よりも個人種目 で「指導者」 $(Z= \pm 9.1, \mathrm{p}<.01)$ 及び「指導者と 一部の生徒」 $(Z= \pm 4.7, \mathrm{p}<.01)$ が決定したと回 答した割合が有意に高かった。 反対に，集団種目 は個人種目よりも，「指導者とすべての生徒」(Z $= \pm 4.4, \mathrm{p}<.01)$ 及び「すべての生徒」 $(Z= \pm$ $3.7, \mathrm{p}<.01)$ で決定したと回答した割合が有意に 高かった。 また学校種別では, 中学生は高校生よ りも「すべての生徒」 $(Z= \pm 10.7, \mathrm{p}<.01)$ で決
定したと回答した割合が有意に高かった。反対 に, 高校生は中学生よりも「指導者と一部の生 徒」 $(Z= \pm 2.5, \mathrm{p}<.05)$ 及び「指導者とすべての 生徒」 $(Z= \pm 9.4, \mathrm{p}<.01)$ で決定したと回答した 割合が有意に高かった.

これらの結果から, チーム目標の決定に際し て, 個人種目では指導者の主導性がより強く発揮 されており, 逆に集団種目及び中学生では生徒の 主体性が十分に尊重されていることが明らかにな った. また, 中学生に比して高校生では, チーム の目標決定に関わって, 指導者が大きく関与して 抢り，影響力が強いことが示された.

さらに，チーム目標の共有状況では，「すべて の生徒が共有している」と回答した割合が $77.5 \%$ （5410名）と最も高く, 一方で「一部の生徒が共 
有していない」は19.3\% (1349名),「ほとんど の生徒が共有していない」は $3.2 \%$ (219名) と 回答した割合は低かった。 $\chi^{2}$ 検定の結果, 運 動種目別 $\left(\chi^{2}(2)=31.71, \mathrm{p}<.001\right.$, Cramer's V $=.068)$, 学校種別 $\left(\chi^{2}(2)=15.52, \mathrm{p}<.001\right.$, Cramer's V=.048) それぞれにおいて有意差が 認められた. 残差分析の結果, 運動種目別では, 集団種目は個人種目よりも $(Z= \pm 5.5, \mathrm{p}<.01)$, 学校種別では高校生は中学生よりも $(Z= \pm 3.3$,

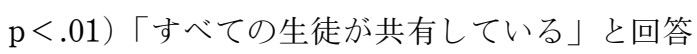
した割合がそれぞれ有意に高かった，反対に，個 人種目 $(Z= \pm 5.5, \quad \mathrm{p}<.01)$ 及び中学生 $(Z= \pm$ $3.9, \mathrm{p}<.01)$ では「一部の生徒が共有していな い」と回答した割合が有意に高かった。これらの 結果から, チームの目標は, 集団種目及び高校生 では目標がある割合だけでなく，すべての生徒が 共有している割合に関しても個人種目及び中学生 を上回っていることが明らかになった．集団種目 では, 普段からチームで活動し仲間と協力してパ フォーマンスを発揮する場面が多いため, 個人種 目よりも集団の凝集性が強く, チームで共通の目 標を設定しようという意識が高いと考えられる.

また高校生は, 中学生よりも自分たちで話し合っ て物事を判断・決定し, 進めていこうという意識 が高いと推察された. 他方で, 中学生は生徒全員 で主体的に目標を決定しているにもかかわらず,

一部の生徒が目標を共有していなかった。これ は, 中学生が自分たちで決定したことをチーム全 員で共有したり確実に実行したりする経験や能力 が未熟であることが原因の1つではないかと考 えられる。

\section{2）個人の目標設定}

表 4 は, 個人目標の有無, 達成計画, 達成努 力に関する生徒の回答を全体の割合, 運動種目別 及び学校種別で分析したものである. その結果, 個人の「目標がある」と回答した割合は $92.8 \%$ （7468名）で，ほとんどの生徒が個人目標を設定 して取り組んでいることが明らかになった。 $\chi^{2}$ 検定の結果, 運動種目別に扔いて有意差が認めら れ $\left(\chi^{2}(1)=13.40, \mathrm{p}<.001, \phi=-.043\right)$, 残差分
析の結果, 集団種目は個人種目よりも, 個人の 「目標がある」と回答した割合が有意に高かった $(Z= \pm 3.7, \mathrm{p}<.01)$. 個人種目に扔いて, 個人の 目標があると回答した割合が低かったのは, 表 3 に扔いて個人種目ではチームの目標設定に関わっ て指導者の関与が大きいことが影響していたと考 えられる。

次に，個人目標の達成計画では，「なんとなく 計画はある」と回答した割合が58.4\%（4360名） と最も高く, 次いで「具体的な計画がある」と回 答した割合が35.1\%（2620名）であり，「計画は ない」と回答した割合は 1 割未満と少なかった. $\chi^{2}$ 検定の結果, 運動種目別に招いて有意差が 認められ $\left(\chi^{2}(2)=10.01, \mathrm{p}<.01\right.$, Cramer's V $=.036)$, 残差分析の結果, 「具体的な計画があ る」と回答した割合は, 個人種目よりも集団種目 の生徒が $(Z= \pm 3.1, \mathrm{p}<.01)$, 反対に「なんとな く計画はある」と回答した割合は, 集団種目より も個人種目の生徒が $(Z= \pm 2.4, \mathrm{p}<.01)$ それぞ れ有意に高かった.

さらに，個人目標の達成努力では，「努力でき ている」と回答した割合が71.6\%（5345名）と 最も高く, 次いで「十分に努力できている」と回 答した割合が14.7\%（1099名）と合わせて $85 \%$ 以上の生徒は個人目標の達成努力ができていると 回答した. $\chi^{2}$ 検定の結果, 学校種別において 有意差が認められ $\left(\chi^{2}(3)=17.80, \mathrm{p}<.001\right.$, Cramer's $\mathrm{V}=.049)$, 残差分析の結果, 「十分に 努力できている」と回答した割合は, 高校生より も中学生が有意に高く $(Z= \pm 3.9, \mathrm{p}<.01)$, また 「努力できている」と回答した割合は, 中学生よ りも高校生が有意に高かった $(Z= \pm 3.7, \mathrm{p}<.01)$.

\section{3）チームの勝利志向性, 生徒の意見の反映 度, 生徒の満足度}

(1) チームの勝利志向性

表 5 は, チームの勝利志向性に対する生徒の 意識を全体の割合, 運動種目別及び学校種別で分 析したものである。その結果，全体でみると， 「徹底して勝つ」と回答した割合が49.1\%（3951 名）と最も高く, 次いで「ある程度勝つことを中 
表 4 運動種目/学校種別にみた個人目標の有無, 達成計画, 達成努力

\begin{tabular}{|c|c|c|c|c|c|c|c|c|c|c|}
\hline \multirow{2}{*}{\multicolumn{2}{|c|}{ 個人の目標 }} & \multirow{3}{*}{\begin{tabular}{|l}
$\begin{array}{l}\text { 全体の } \\
\text { 割合 }\end{array}$ \\
$\begin{array}{l}92.8 \% \\
(7468)\end{array}$ \\
\end{tabular}} & \multicolumn{2}{|c|}{ 運動種目 } & \multirow[b]{2}{*}{ 残差 } & \multirow[b]{2}{*}{$\begin{array}{l}\chi_{(\mathrm{f})}^{2} \text { 値 } \\
(\mathrm{df})\end{array}$} & \multicolumn{2}{|c|}{ 学校種 } & \multirow[b]{2}{*}{ 残差 } & \multirow[b]{2}{*}{$\begin{array}{l}\chi^{2} \text { 値 } \\
(\mathrm{df})\end{array}$} \\
\hline & & & \multicolumn{2}{|c|}{\begin{tabular}{c|c} 
個人 & 集目 \\
度数（\%)
\end{tabular}} & & & \multicolumn{2}{|c|}{\begin{tabular}{c|c} 
中学生 & 高校生 \\
度数 $(\%)$
\end{tabular}} & & \\
\hline \multirow{3}{*}{$\begin{array}{l}\text { 有 } \\
\text { 無 }\end{array}$} & 目標がある & & $\begin{array}{r}3354 \\
(91.6 \%)\end{array}$ & $\begin{array}{r}4114 \\
(93.7 \%)\end{array}$ & $\begin{array}{r} \pm 3.7 \\
* *\end{array}$ & \multirow{3}{*}{$\begin{array}{c}13.40 \\
* * * \\
(1)\end{array}$} & $\begin{array}{r}3804 \\
(92.6 \%)\end{array}$ & $\begin{array}{r}3664 \\
(92.9 \%)\end{array}$ & \pm 0.4 & \multirow{2}{*}{$\begin{array}{l}0.14 \\
(1)\end{array}$} \\
\hline & 目標がない & $\begin{array}{l}7.2 \% \\
(580) \\
\end{array}$ & $\begin{array}{r}306 \\
(8.4 \%) \\
\end{array}$ & $\begin{array}{r}274 \\
(6.2 \%)\end{array}$ & $\begin{array}{r} \pm 3.7 \\
* * \\
\end{array}$ & & $\begin{array}{r}300 \\
(7.3 \%)\end{array}$ & $\begin{array}{r}280 \\
(7.1 \%)\end{array}$ & \pm 0.4 & \\
\hline & 計 & $\begin{array}{r}100 \% \\
(8048)\end{array}$ & $\begin{array}{r}3660 \\
(100 \%)\end{array}$ & $\begin{array}{r}4388 \\
(100 \%)\end{array}$ & & & $\begin{array}{r}4104 \\
(100 \%)\end{array}$ & $\begin{array}{r}3944 \\
(100 \%)\end{array}$ & & \\
\hline \multirow{4}{*}{ 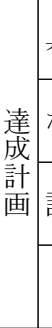 } & 具体的な計画がある & $\begin{array}{l}35.1 \% \\
(2620)\end{array}$ & $\begin{array}{r}1113 \\
(33.2 \%)\end{array}$ & $\begin{array}{r}1507 \\
(36.6 \%)\end{array}$ & $\begin{array}{r} \pm 3.1 \\
* *\end{array}$ & \multirow{4}{*}{$\begin{array}{c}10.01 \\
(2)^{* *}\end{array}$} & $\begin{array}{r}1312 \\
(34.5 \%)\end{array}$ & $\begin{array}{r}1308 \\
(35.7 \%)\end{array}$ & \pm 1.1 & \multirow{3}{*}{$\begin{array}{l}1.28 \\
(2)\end{array}$} \\
\hline & なんとなく計画はある & $\begin{array}{l}58.4 \% \\
(4360)\end{array}$ & $\begin{array}{r}2008 \\
(59.9 \%) \\
\end{array}$ & $\begin{array}{r}2352 \\
(57.2 \%) \\
\end{array}$ & $\begin{array}{r} \pm 2.4 \\
* \\
\end{array}$ & & $\begin{array}{r}2236 \\
(58.8 \%) \\
\end{array}$ & $\begin{array}{r}2124 \\
(58.0 \%)\end{array}$ & \pm 0.8 & \\
\hline & 計画はない & $\begin{array}{l}6.5 \% \\
(485)\end{array}$ & $\begin{array}{r}231 \\
(6.9 \%)\end{array}$ & $\begin{array}{r}254 \\
(6.2 \%)\end{array}$ & \pm 1.2 & & $\begin{array}{r}253 \\
(6.7 \%)\end{array}$ & $\begin{array}{r}232 \\
(6.3 \%)\end{array}$ & \pm 0.6 & \\
\hline & 計 & $\begin{array}{r}100 \% \\
(7465)\end{array}$ & $\begin{array}{r}3352 \\
(100 \%) \\
\end{array}$ & $\begin{array}{r}4113 \\
(100 \%)\end{array}$ & & & $\begin{array}{r}3801 \\
(100 \%)\end{array}$ & $\begin{array}{r}3664 \\
(100 \%)\end{array}$ & & \\
\hline & 十分に努力できている & $\begin{array}{l}14.7 \% \\
(1099)\end{array}$ & $\begin{array}{r}500 \\
(14.9 \%)\end{array}$ & $\begin{array}{r}599 \\
(14.6 \%)\end{array}$ & \pm 0.4 & \multirow{4}{*}{$\begin{array}{l}1.17 \\
(3)\end{array}$} & $\begin{array}{r}620 \\
(16.3 \%)\end{array}$ & $\begin{array}{r}479 \\
(13.1 \%)\end{array}$ & $\begin{array}{r} \pm 3.9 \\
* *\end{array}$ & \multirow{4}{*}{$\begin{array}{c}17.80 \\
* * * \\
(3)\end{array}$} \\
\hline 達 & 努力できている & $\begin{array}{l}71.6 \% \\
(5345)\end{array}$ & $\begin{array}{r}2404 \\
(71.7 \%) \\
\end{array}$ & $\begin{array}{r}2941 \\
(71.5 \%) \\
\end{array}$ & \pm 0.2 & & $\begin{array}{r}2650 \\
(69.7 \%) \\
\end{array}$ & $\begin{array}{r}2695 \\
(73.6 \%) \\
\end{array}$ & $\begin{array}{r} \pm 3.7 \\
* *\end{array}$ & \\
\hline $\begin{array}{l}\text { 成 } \\
\text { 努 }\end{array}$ & あまり努力していない & $\begin{array}{r}13.2 \% \\
(985) \\
\end{array}$ & \begin{tabular}{|r|}
430 \\
$(12.8 \%)$ \\
\end{tabular} & $\begin{array}{r}555 \\
(13.5 \%) \\
\end{array}$ & \pm 0.8 & & $\begin{array}{r}511 \\
(13.4 \%) \\
\end{array}$ & $\begin{array}{r}474 \\
(12.9 \%) \\
\end{array}$ & \pm 0.6 & \\
\hline \multirow[t]{2}{*}{ 力 } & ほとんど努力していない & $\begin{array}{r}0.5 \% \\
(36)\end{array}$ & $\begin{array}{r}18 \\
(0.5 \%)\end{array}$ & $\begin{array}{r}18 \\
(0.4 \%)\end{array}$ & \pm 0.6 & & $\begin{array}{r}20 \\
(0.5 \%)\end{array}$ & $\begin{array}{r}16 \\
(0.4 \%)\end{array}$ & \pm 0.6 & \\
\hline & 計 & $\begin{array}{r}100 \% \\
(7465)\end{array}$ & $\begin{array}{r}3352 \\
(100 \%)\end{array}$ & $\begin{array}{r}4113 \\
(100 \%)\end{array}$ & & & $\begin{array}{r}3801 \\
(100 \%)\end{array}$ & $\begin{array}{r}3664 \\
(100 \%)\end{array}$ & & \\
\hline
\end{tabular}

表 5 運動種目/学校種別にみたチームの勝利志向性に対する生徒の意識

\begin{tabular}{|c|c|c|c|c|c|c|c|c|c|}
\hline \multirow{2}{*}{ チームの勝利志向性 } & \multirow[b]{2}{*}{$\begin{array}{l}\text { 全体の } \\
\text { 割合 }\end{array}$} & \multicolumn{2}{|c|}{ 運動種目 } & \multirow[b]{2}{*}{$\begin{array}{l}\text { 残差 } \\
\text { 分析 }\end{array}$} & \multirow[b]{2}{*}{$\begin{array}{c}\chi^{2} \text { 値 } \\
(\mathrm{df})\end{array}$} & \multicolumn{2}{|c|}{ 学校種 } & \multirow[b]{2}{*}{$\begin{array}{l}\text { 残差 } \\
\text { 分析 }\end{array}$} & \multirow[b]{2}{*}{$\begin{array}{l}\chi^{2} \text { 值 } \\
(\mathrm{df})\end{array}$} \\
\hline & & \multicolumn{2}{|c|}{ 度数 $(\%)$} & & & $\begin{array}{l}\text { 中学生 } \\
\text { 度数 }\end{array}$ & $\begin{array}{l}\text { 高校生 } \\
(\%)\end{array}$ & & \\
\hline 徹底して勝つ & $\begin{array}{l}49.1 \% \\
(3951)\end{array}$ & $\begin{array}{r}1429 \\
(39.0 \%)\end{array}$ & $\begin{array}{r}2522 \\
(57.5 \%)\end{array}$ & $\begin{array}{r} \pm 16.5 \\
* *\end{array}$ & \multirow{4}{*}{$\begin{array}{c}294.04 \\
* * * \\
(3)\end{array}$} & $\begin{array}{r}1961 \\
(47.8 \%)\end{array}$ & $\begin{array}{r}1990 \\
(50.5 \%)\end{array}$ & $\begin{array}{r}2.4 \\
*\end{array}$ & \multirow{4}{*}{$\begin{array}{l}7.66 \\
(3)\end{array}$} \\
\hline ある程度勝つことを中心に楽しむ & $\begin{array}{l}39.7 \% \\
(3193)\end{array}$ & $\begin{array}{r}1679 \\
(45.9 \%) \\
\end{array}$ & $\begin{array}{r}1514 \\
(34.5 \%) \\
\end{array}$ & $\begin{array}{r} \pm 10.4 \\
* * \\
\end{array}$ & & $\begin{array}{r}1688 \\
(41.1 \%)\end{array}$ & $\begin{array}{r}1505 \\
(38.2 \%) \\
\end{array}$ & $\begin{array}{r} \pm 2.7 \\
* * \\
\end{array}$ & \\
\hline $\begin{array}{l}\text { みんなで楽しむことを中心に } \\
\text { できれば勝つ }\end{array}$ & $\begin{array}{l}9.2 \% \\
(741)\end{array}$ & $\begin{array}{r}444 \\
(12.1 \%)\end{array}$ & $\begin{array}{r}297 \\
(6.8 \%)\end{array}$ & $\begin{array}{r} \pm 8.3 \\
* *\end{array}$ & & $\begin{array}{r}371 \\
(9.0 \%)\end{array}$ & $\begin{array}{r}370 \\
(9.4 \%)\end{array}$ & \pm 0.5 & \\
\hline とことん楽しむ & $\begin{array}{l}2.0 \% \\
(161)\end{array}$ & $\begin{array}{r}107 \\
(2.9 \%)\end{array}$ & $\begin{array}{r}54 \\
(1.2 \%)\end{array}$ & $\begin{array}{r} \pm 5.4 \\
* *\end{array}$ & & $\begin{array}{r}82 \\
(2.0 \%)\end{array}$ & $\begin{array}{r}79 \\
(2.0 \%)\end{array}$ & \pm 0.0 & \\
\hline 不 & $(2)$ & 1 & 1 & & & 2 & 0 & & \\
\hline 計 & $\begin{array}{c}100 \% \\
(8048)\end{array}$ & $\begin{array}{r}3660 \\
(100 \%)\end{array}$ & $\begin{array}{r}4388 \\
(100 \%)\end{array}$ & & & $\begin{array}{r}4104 \\
(100 \%)\end{array}$ & $\begin{array}{r}3944 \\
(100 \%)\end{array}$ & & \\
\hline
\end{tabular}


心に楽しむ」と回答した割合が39.7\%（3193名） といったように 9 割近くの生徒はチームの勝利 を目指すことを中心に考えており，「楽しむ」こ とを中心に考える生徒は少なかった。文部省 （1997）の調查では，「ある程度勝つことを中心 に楽しむ」と回答した割合（中学生 $56.5 \%$, 高校 生62.6\%）が最も高く, 次いで「みんなで楽しむ ことを中心にできれば勝つ」という回答（中学生 $21.2 \%$ ，高校生 $18.8 \%$ ）の順であり，「徹底して 勝つ」と回答した割合（中学生 $11.8 \%$, 高校生 12.1\%）は低かったことから, 本研究の対象者が チームの勝利をより重視していることが明らかに なった。 $\chi^{2}$ 検定の結果, 運動種目別 $\left(\chi^{2}(3)=\right.$ 294.04, $\mathrm{p}<.001$, Cramer's V=.165), 学校種別 $\left(\chi^{2}(3)=7.66, \mathrm{p}<.05\right.$, Cramer's V=.032) それぞ れに打いて有意差が認められた。残差分析の結 果,「徹底して勝つ」と回答した割合は, 個人種 目よりも集団種目の方 $(Z= \pm 16.5, \mathrm{p}<.01)$ が， また中学生よりも高校生の方 $(Z= \pm 2.4, \mathrm{p}<.05)$ がそれぞれ有意に高かった，反対に，「ある程度 勝つことを中心に楽しむ」と回答した割合は，集 団種目よりも個人種目の方 $(Z= \pm 10.4, \mathrm{p}<.01)$ が, 高校生よりも中学生の方 $(Z= \pm 2.7, \mathrm{p}<.05)$ がそれぞれ有意に高かった。 また，「みんなで楽 しむことを中心にできれば勝つ」 $(Z= \pm 8.3$ ， $\mathrm{p}<.01), 「$ とことん楽しむ」 $(Z= \pm 5.4, \mathrm{p}<.01)$
それぞれに回答した割合は，集団種目よりも個人 種目が有意に高かった。この結果から, 集団種目 と比べて個人種目の生徒は楽しむことを重視する 傾向が明らかになった。

（2）生徒の意見の反映度

表 6 は, 練習や試合に打ける生徒の意見の反 映度について全体の割合, 運動種目別及び学校種 別で分析したものである，その結果，全体でみる と「反映されている」と回答した割合が $59.4 \%$ （4783名）と最も高く，次いで「とても反映され ている」が20.6\%（1657名）であり，多くの生 徒が練習や試合に扔いて自分たちの意見が反映さ れていると回答した. 学校種別でみると, 中学生 の78.8\%（3238名), 高校生の81.2\%（3202名） が（「とても反映されている」を含めて）反映さ れていると回答し，文部省（1997）の調査とほ ぼ同様の結果が認められた注6)。この結果から， 多くの運動部活動では生徒の考えや意見が取り入 れられ, 生徒の主体性が尊重されていることが推 察された。

$\chi^{2}$ 検定の結果, 運動種目別 $\left(\chi^{2}(3)=15.68\right.$, $\mathrm{p}<.01$, Cramer's V=.003), 学校種別 $\left(\chi^{2}(3)=\right.$ $7.86, \mathrm{p}<.05$, Cramer's V=.029）それぞれにおい て有意差が認められた．残差分析の結果，「とて も反映されている」と回答した割合は，個人種目 よりも集団種目の方が有意に高かった $(Z= \pm$

表 6 運動種目/学校種別にみた生徒の意見の反映度

\begin{tabular}{|c|c|c|c|c|c|c|c|c|c|}
\hline \multirow[b]{2}{*}{ 生徒の意見の反映度 } & \multirow[b]{2}{*}{$\begin{array}{l}\text { 全体の } \\
\text { 割合 }\end{array}$} & \multicolumn{2}{|c|}{ 運動種目 } & \multirow[b]{2}{*}{$\begin{array}{l}\text { 残差 } \\
\text { 分析 }\end{array}$} & \multirow[b]{2}{*}{$\begin{array}{l}\chi^{2} \text { 值 } \\
(\mathrm{df})\end{array}$} & \multicolumn{2}{|c|}{ 学校種 } & \multirow[b]{2}{*}{$\begin{array}{l}\text { 残差 } \\
\text { 分析 }\end{array}$} & \multirow[b]{2}{*}{$\begin{array}{c}\chi^{2} \text { 值 } \\
(\mathrm{df})\end{array}$} \\
\hline & & $\begin{array}{c}\text { 個人 } \\
\text { 度数 }\end{array}$ & $\begin{array}{l}\text { 集団 } \\
(\%)\end{array}$ & & & $\begin{array}{c}\text { 中学生 } \\
\text { 度数 }\end{array}$ & $\begin{array}{l}\text { 高校生 } \\
(\%)\end{array}$ & & \\
\hline とても反映されている & $\begin{array}{l}20.6 \% \\
(1657)\end{array}$ & $\begin{array}{r}695 \\
(19.0 \%)\end{array}$ & $\begin{array}{r}962 \\
(21.9 \%)\end{array}$ & $\begin{array}{r} \pm 3.2 \\
* *\end{array}$ & \multirow{4}{*}{$\begin{array}{c}15.68 \\
* * \\
(3)\end{array}$} & $\begin{array}{r}851 \\
(20.7 \%)\end{array}$ & $\begin{array}{r}806 \\
(20.4 \%)\end{array}$ & \pm 0.3 & \multirow{4}{*}{$\begin{array}{l}7.86 \\
{ }_{(3)}^{*}\end{array}$} \\
\hline 反映されている & $\begin{array}{l}59.4 \% \\
(4783)\end{array}$ & $\begin{array}{r}2242 \\
(61.3 \%) \\
\end{array}$ & $\begin{array}{r}2541 \\
(57.9 \%) \\
\end{array}$ & $\begin{array}{r} \pm 3.1 \\
* *\end{array}$ & & $\begin{array}{r}2387 \\
(58.1 \%) \\
\end{array}$ & $\begin{array}{r}2396 \\
(60.8 \%) \\
\end{array}$ & $\begin{array}{r} \pm 2.4 \\
*\end{array}$ & \\
\hline あまり反映されていない & $\begin{array}{l}17.3 \% \\
(1389)\end{array}$ & $\begin{array}{r}612 \\
(16.7 \%)\end{array}$ & $\begin{array}{r}777 \\
(17.7 \%)\end{array}$ & \pm 1.2 & & $\begin{array}{r}745 \\
(18.2 \%)\end{array}$ & $\begin{array}{r}644 \\
(16.3 \%)\end{array}$ & $\begin{array}{r} \pm 2.2 \\
*\end{array}$ & \\
\hline ほとんど反映されていない & $\begin{array}{l}2.7 \% \\
(219)\end{array}$ & $\begin{array}{r}111 \\
(3.0 \%)\end{array}$ & $\begin{array}{r}108 \\
(2.5 \%)\end{array}$ & \pm 1.6 & & $\begin{array}{r}121 \\
(2.9 \%)\end{array}$ & $\begin{array}{r}98 \\
(2.5 \%)\end{array}$ & \pm 1.3 & \\
\hline 合 & $\begin{array}{l}100 \% \\
(8048)\end{array}$ & $\begin{array}{r}3660 \\
(100 \%)\end{array}$ & $\begin{array}{r}4388 \\
(100 \%)\end{array}$ & & & $\begin{array}{r}4104 \\
(100 \%)\end{array}$ & $\begin{array}{r}3944 \\
(100 \%)\end{array}$ & & \\
\hline
\end{tabular}


$3.2, \mathrm{p}<.01)$ が，「反映されている」と回答した 割合は，集団種目よりも個人種目の方が有意に高 かった $(Z= \pm 3.1, \mathrm{p}<.01)$. 他方で, 中学生は高 校生よりも「反映されている」と回答した割合が 有意に低く $(Z= \pm 2.4, \mathrm{p}<.05)$ ，逆に「あまり反 映されていない」と回答した割合が有意に高かっ た $(Z= \pm 2.2, \mathrm{p}<.05)$. この結果から, 高校生と 比較して中学生の運動部活動では, 練習や試合に 関わって生徒の考えや意見が取り入れられていな いことが示された.

（3）運動部活動に対する生徒の満足度

表 7 は, 運動部活動に対する生徒の満足度に ついて全体の割合, 運動種目別及び学校種別で分 析したものである.その結果，全体では「とても 楽しい」と回答した割合が59.7\%（4802名）と 最も高く，次いで「どちらかというと楽しい」と 回答した割合は $32.9 \%$ （2648名）であり，9 割以 上の生徒が運動部活動を楽しいと回答していた.

学校種別でみると, 中学生の93.0\%（3818 名), 高校生の $92.1 \%$ （3632名）が運動部活動を 楽しいと回答していた。文部省（1997）の調査 では, 中学生の83.4\%, 高校生の83.8\%が（「と ても/どちらかというと楽しい」を含めて）楽し いと回答していたことから, 本研究で対象となっ た生徒は，運動部活動に対する満足度の高い生徒 が多いことが示された。 $\chi^{2}$ 検定の結果, 運動種
目別 $\left(\chi^{2}(3)=17.29, \mathrm{p}<.01\right.$, Cramer's $\left.\mathrm{V}=.016\right)$, 学校種別 $\left(\chi^{2}(3)=7.43, \quad \mathrm{p}<.05\right.$, Cramer's V =.018）それぞれにおいて有意差が認められた. 残差分析の結果，集団種目は個人種目よりも（Z $= \pm 2.5, \mathrm{p}<.05)$, 中学生は高校生よりも $(\mathrm{Z}= \pm$ $2.5, \mathrm{p}<.05) 「 と て も$ 楽しい」と回答した割合が 有意に高かった。また，「どちらかというと苦し い」と回答した割合もまた，個人種目よりも集団 種目の方が有意に高かった $(Z= \pm 2.4, \mathrm{p}<.05)$. この結果から，個人種目と比較して集団種目は， 生徒にとって楽しいだけではなく，苦しさも味わ える種目であることが示唆された。

\section{4）目標の有無, 生徒の属性, 生徒の意見の反 映度, チームの勝利志向性と生徒の満足度 との関係}

ここまで運動部活動におけるチーム/個人の目 標設定, チームの勝利志向性, 生徒の意見の反映 度さらには生徒の満足度について分析した。ここ では, チーム/個人の目標設定, チームの勝利志 向性，生徒の意見の反映度をそれぞれ独立変数と して設定し，そのうちどれが運動部活動に対する 生徒の満足度に影響を及ぼすかを検討した。

（1）目標の有無, 生徒の属性, 生徒の意見の反 映度, チームの勝利志向性と生徒の満足度との関 係

表 7 運動種目/学校種別にみた運動部活動に対する生徒の満足度

\begin{tabular}{|c|c|c|c|c|c|c|c|c|c|}
\hline \multirow[b]{2}{*}{ 生徒の満足度 } & \multirow[b]{2}{*}{$\mid \begin{array}{c}\text { 全体の } \\
\text { 割合 }\end{array}$} & \multicolumn{2}{|c|}{ 運動種目 } & \multirow[b]{2}{*}{$\begin{array}{l}\text { 残差 } \\
\text { 分析 }\end{array}$} & \multirow[b]{2}{*}{$\begin{array}{c}\chi^{2} \text { 值 } \\
(\mathrm{df})\end{array}$} & \multicolumn{2}{|c|}{ 学校種 } & \multirow[b]{2}{*}{$\begin{array}{l}\text { 残差 } \\
\text { 分析 }\end{array}$} & \multirow[b]{2}{*}{$\begin{array}{l}\chi^{2} \text { 值 } \\
(\mathrm{df})\end{array}$} \\
\hline & & $\begin{array}{l}\text { 個人 } \\
\text { 度数 }\end{array}$ & $\begin{array}{l}\text { 集団 } \\
(\%)\end{array}$ & & & $\begin{array}{c}\text { 中学生 } \\
\text { 度数 }\end{array}$ & $\begin{array}{l}\text { 高校生 } \\
(\%)\end{array}$ & & \\
\hline とても楽しい & $\begin{array}{l}59.7 \% \\
(4802)\end{array}$ & $\begin{array}{r}2130 \\
(58.2 \%)\end{array}$ & $\begin{array}{r}2672 \\
(60.9 \%)\end{array}$ & $\begin{array}{r} \pm 2.5 \\
*\end{array}$ & \multirow{4}{*}{$\begin{array}{c}17.29 \\
(3)^{* *}\end{array}$} & $\begin{array}{r}2504 \\
(61.0 \%)\end{array}$ & $\begin{array}{r}2298 \\
(58.3 \%)\end{array}$ & $\begin{array}{r} \pm 2.5 \\
*\end{array}$ & \multirow{4}{*}{$\begin{array}{l}7.43 \\
{ }_{(3)}^{*}\end{array}$} \\
\hline どちらかというと楽しい & $\begin{array}{l}32.9 \% \\
(2648)\end{array}$ & $\begin{array}{r}1280 \\
(35.0 \%)\end{array}$ & $\begin{array}{r}1368 \\
(31.2 \%)\end{array}$ & $\begin{array}{r} \pm 3.6 \\
* *\end{array}$ & & $\begin{array}{r}1314 \\
(32.0 \%)\end{array}$ & $\begin{array}{r}1334 \\
(33.8 \%)\end{array}$ & \pm 1.7 & \\
\hline どちらかというと苦しい & $\begin{array}{l}6.3 \% \\
(508)\end{array}$ & $\begin{array}{r}205 \\
(5.6 \%)\end{array}$ & $\begin{array}{r}303 \\
(6.9 \%)\end{array}$ & $\begin{array}{r} \pm 2.4 \\
*\end{array}$ & & $\begin{array}{r}246 \\
(6.0 \%)\end{array}$ & $\begin{array}{r}262 \\
(6.6 \%)\end{array}$ & \pm 1.2 & \\
\hline とても苦しい & $\begin{array}{r}1.1 \% \\
(90)\end{array}$ & $\begin{array}{r}45 \\
(1.2 \%)\end{array}$ & $\begin{array}{r}45 \\
(1.0 \%)\end{array}$ & \pm 0.9 & & $\begin{array}{r}40 \\
(1.0 \%)\end{array}$ & $\begin{array}{r}50 \\
(1.3 \%)\end{array}$ & \pm 1.2 & \\
\hline 計 & $\begin{array}{r}100 \% \\
(8048)\end{array}$ & $\begin{array}{r}3660 \\
(100 \%)\end{array}$ & $\begin{array}{r}4388 \\
(100 \%)\end{array}$ & & & $\begin{array}{r}4104 \\
(100 \%)\end{array}$ & $\begin{array}{r}3944 \\
(100 \%)\end{array}$ & & \\
\hline
\end{tabular}


表 8 は, 運動部活動に対する生徒の満足度を 従属变数, 他の各測定項目を独立变数として重回 帰分析（カテゴリカル回帰）を行った結果を示し たものである. その結果, 標準偏回帰係数 $\beta$ 值 から, 生徒の意見の反映度 $(\beta=.193, \mathrm{p}<.001)$, 個人目標の有無 $(\beta=.103, \mathrm{p}<.001)$, チームの勝 利志向性 $(\beta=.085, \mathrm{p}<.001)$ は，生徒の満足度 に有意な正の影響を及ぼしていることが認められ

表 8 目標の有無, 生徒の属性, 生徒の意見の反映度及 びチームの勝利志向性と生徒の満足度との関係

\begin{tabular}{|c|c|}
\hline & 標準偏回帰係数 $(\beta)$ \\
\hline \multirow{2}{*}{ 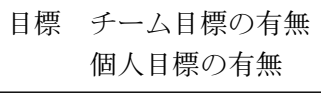 } & .007 \\
\hline & $.103^{* * *}$ \\
\hline \multirow[t]{2}{*}{ 生徒の属性 } & .020 \\
\hline & .016 \\
\hline \multirow{2}{*}{$\begin{array}{l}\text { 生徒の意見の反映度 } \\
\text { チームの勝利志向性 }\end{array}$} & $.193^{* * *}$ \\
\hline & $.085^{* * *}$ \\
\hline $\mathrm{R}^{2}$ & $.066^{* * *}$ \\
\hline
\end{tabular}

た。チーム目標の有無では有意な影響はみられな かった一方で注7)，個人目標の有無が生徒の満足 度に影響を与えていることが示された。しかしな がら, 生徒の満足度の決定係数 $\mathrm{R}^{2}$ は有意ではあ ったが比較的低い值であった。

さらに，生徒の満足度に対して有意な正の影響 を及ぼした個人目標の有無, チームの勝利志向 性, 生徒の意見の反映度について, 満足度の高低 に影響する各変数の期待度数と測定值との間でぞ の程度の差異がみられるかを明らかにするために $\chi^{2}$ 検定を行った。ちなみに，生徒の満足度を明 確に区分するために，「とても楽しい」と「どち らかといえば楽しい」を「楽しい」に，また「と ても苦しい」と「どちらかといえば苦しい」を 「苦しい」にそれぞれまとめて二件法で分析した。

（2）個人の目標設定と生徒の満足度との関係 表 9 は, 個人目標の有無, 達成計画, 達成努 力と生徒の満足度との関係を分析したものであ る。まず，個人目標の有無による生徒の満足度の 差を $\chi^{2}$ 検定した結果, 有意差が認められた（ $\chi^{2}$ $(1)=148.75, \mathrm{p}<.001, \phi=-.136)$. 残差分析の

表 9 個人目標の有無, 達成計画, 達成努力と生徒の満足度との関係

\begin{tabular}{|c|c|c|c|c|c|}
\hline \multicolumn{2}{|c|}{ 個人の目標 } & $\begin{array}{l}\text { 楽しい } \\
\text { 度数（\%) }\end{array}$ & $\begin{array}{l}\text { 苦しい } \\
\text { 度数（\%) }\end{array}$ & 残差分析 & $\begin{array}{c}\chi^{2} \text { 值 } \\
(\mathrm{df})\end{array}$ \\
\hline \multirow{4}{*}{ 有 無 } & 目標がある & $6987(93.8 \%)$ & $478(80.3 \%)$ & $\pm 12.2^{* *}$ & \multirow{2}{*}{$\begin{array}{c}148.75^{* * * *} \\
\text { (1) }\end{array}$} \\
\hline & 目標がない & $463(6.2 \%)$ & $117(19.7 \%)$ & $\pm 12.2^{* *}$ & \\
\hline & 不 & 0 & 3 & & \\
\hline & 合 & $7450(100 \%)$ & $598(100 \%)$ & & \\
\hline \multirow{4}{*}{ 達成計画 } & 具体的な計画がある & $2500(35.8 \%)$ & $120(25.1 \%)$ & $\pm 4.7^{* *}$ & \multirow{3}{*}{$\begin{array}{c}44.55^{* * *} \\
(2)\end{array}$} \\
\hline & なんとなく計画はある & $4062(58.1 \%)$ & $298(62.3 \%)$ & $\pm 1.8^{*}$ & \\
\hline & 計画はない & $425(6.1 \%)$ & $60(12.6 \%)$ & $\pm 5.6^{* *}$ & \\
\hline & 合 & $6987(100 \%)$ & $478(100 \%)$ & & \\
\hline \multirow{5}{*}{ 達成努力 } & 十分に努力できている & $1066(15.3 \%)$ & $33(6.9 \%)$ & $\pm 5.0^{* *}$ & \multirow{4}{*}{$\begin{array}{c}146.15^{\text {**** }} \\
\text { (3) }\end{array}$} \\
\hline & 努力できている & $5041(72.1 \%)$ & $304(63.6 \%)$ & $\pm 4.1^{* *}$ & \\
\hline & あまり努力していない & $856(12.3 \%)$ & $129(27.0 \%)$ & $\pm 9.3^{* *}$ & \\
\hline & ほとんど努力していない & $24(0.3 \%)$ & $12(2.5 \%)$ & $\pm 6.7^{* *}$ & \\
\hline & 計 & $6987(100 \%)$ & $478(100 \%)$ & & \\
\hline
\end{tabular}


結果, 運動部活動が「楽しい」と回答した生徒は, 「苦しい」と回答した生徒よりも，自分には「目 標がある」と回答した生徒の割合が有意に高かっ た $(\mathrm{Z}= \pm 12.2, \mathrm{p}<.01)$. この結果から, 運動部 活動では明確な個人目標を設定している生徒は満 足度が高いことが示された。

次に, 個人目標の達成計画による生徒の満足度 の差を $\chi^{2}$ 検定した結果, 有意差が認められた $\left(\chi^{2}(2)=44.55, \mathrm{p}<.001\right.$, Cramer's $\left.\mathrm{V}=.078\right)$. 残 差分析の結果, 運動部活動が「楽しい」と回答し た生徒は,「苦しい」と回答した生徒に比べ, 個 人目標の達成に向けた「具体的な計画がある」と 回答した割合が有意に高かった（ $Z= \pm 4.7$, $\mathrm{p}<.01)$. 反対に, 「苦しい」と回答した生徒は, 「なんとなく計画はある」 $(Z= \pm 1.8, \quad \mathrm{p}<.05)$ ， 「計画はない」 $(Z= \pm 5.6, \mathrm{p}<.01)$ と回答した割 合が有意に高かった.

さらに，個人目標の達成努力による生徒の満足 度の差を $\chi^{2}$ 検定した結果, 有意差が認められた $\left(\chi^{2}(3)=146.15, \mathrm{p}<.001\right.$, Cramer's V $\left.=.140\right)$. 残 差分析の結果, 運動部活動が「楽しい」と回答し た生徒は，「苦しい」と回答した生徒に比べ，個 人目標の達成に向けて「十分に努力できている」 $(Z= \pm 5.0, \quad \mathrm{p}<.01)$,「努力できている」 $(Z= \pm$ $4.1, \mathrm{p}<.01 ）$ と回答した割合が有意に高かった. 反対に，運動部活動が「苦しい」と回答した生徒 は，「楽しい」と回答した生徒に比べ「あまり努 力していない」 $(Z= \pm 9.3, \mathrm{p}<.01)$ ，「ほとんど努 力していない」 $(Z= \pm 6.7, \mathrm{p}<.01)$ と回答した割
合が有意に高かった。これらの結果から, 個人目 標の達成に向けて具体的な計画を立て, その達成 に向けて努力ができている生徒は満足度が高いこ とが示唆された。

（3）チームの勝利志向性及び生徒の意見の反映 度と生徒の満足度との関係

表10は, チームの勝利志向性と運動部活動に 対する生徒の満足度との関係を分析したものであ る. チームの勝利志向性の違いによる生徒の満足 度の差を $\chi^{2}$ 検定した結果, 有意差が認められた $\left(\chi^{2}(3)=103.80, \mathrm{p}<.001\right.$, Cramer's $\left.\mathrm{V}=.114\right)$. 残差分析の結果, 運動部活動が「楽しい」と回答 した生徒は，「苦しい」と回答した生徒に比べ, 自分のチームが「ある程度勝つことを中心に楽し む」ことを目指していると回答した割合が有意に 高かった $(Z= \pm 5.7, \quad \mathrm{p}<.01)$. この結果から， 「ある程度勝つことを中心に楽しむ」生徒は満足 度が高いことが示された，反対に，「苦しい」と 回答した生徒は,「楽しい」と回答した生徒に比 べ「みんなで楽しむことを中心にできれば勝つ」 $(Z= \pm 5.0, \mathrm{p}<.01), 「 と こ と ん$ 楽しむ」 $(Z= \pm$ $7.9, \mathrm{p}<.01)$ ことを目指している割合が有意に高 かった。この結果から, 運動部活動に扔いて, 楽 しむことを直接的に目指している生徒が必ずしも 楽しめているとは限らず, チームで共通の目標達 成に向けて活動することの難しさが示唆された。

表11は, 生徒の意見の反映度と運動部活動に 対する生徒の満足度との関係を分析したものであ る. 反映度の違いによる生徒の満足度の差を $\chi^{2}$

表10 チームの勝利志向性と生徒の満足度との関係

\begin{tabular}{|c|c|c|c|c|}
\hline チームの勝利志向性 満足度 & $\begin{array}{l}\text { 楽しい } \\
\text { 度数（\%) }\end{array}$ & $\begin{array}{l}\text { 苦しい } \\
\text { 度数（\%) }\end{array}$ & 残差分析 & $\begin{array}{l}\chi_{(}^{2} \text { 值 } \\
(\mathrm{df})\end{array}$ \\
\hline 徹底して勝つ & $3652(49.0 \%)$ & $299(50.2 \%)$ & \pm 0.5 & \multirow{4}{*}{$\begin{array}{l}103.80^{* * * *} \\
(3)\end{array}$} \\
\hline ある程度勝つことを中心に楽しむ & $3022(40.6 \%)$ & $171(28.7 \%)$ & $\pm 5.7^{* *}$ & \\
\hline みんなで楽しむことを中心にできれば勝つ & $653(8.8 \%)$ & $88(14.8 \%)$ & $\pm 5.0 * *$ & \\
\hline とことん楽しむ & $123(1.7 \%)$ & $38(6.4 \%)$ & $\pm 7.9^{* *}$ & \\
\hline 明 & 0 & 2 & & \\
\hline 計 & $7450(100 \%)$ & $598(100 \%)$ & & \\
\hline
\end{tabular}


表11 生徒の意見の反映度と生徒の満足度との関係

\begin{tabular}{|c|c|c|c|c|}
\hline 生徒の意見の反映度 満足度 & $\begin{array}{l}\text { 楽しい } \\
\text { 度数 }(\%)\end{array}$ & $\begin{array}{l}\text { 苦しい } \\
\text { 度数（\%) }\end{array}$ & 残差分析 & $\begin{array}{c}\chi_{(\mathrm{df})}^{2} \text { 値 } \\
(\mathrm{d})\end{array}$ \\
\hline とても反映されている & $1611(21.6 \%)$ & $46(7.7 \%)$ & $\pm 8.1^{* *}$ & \multirow{4}{*}{${ }_{(3)}^{408.06^{* * *}}$} \\
\hline 反映されている & $4529(60.8 \%)$ & $253(42.3 \%)$ & $\pm 8.9^{* *}$ & \\
\hline あまり反映されていない & $1166(15.7 \%)$ & $223(37.3 \%)$ & $\pm 13.5^{* *}$ & \\
\hline ほとんど反映されていない & $143(1.9 \%)$ & $76(12.7 \%)$ & $\pm 15.7^{* *}$ & \\
\hline 明 & 1 & 0 & & \\
\hline 合計 & $7450(100 \%)$ & $598(100 \%)$ & & \\
\hline
\end{tabular}

検定した結果, 有意差が認められた $\left(\chi^{2}(3)=\right.$ 408.06, $\mathrm{p}<.001$, Cramer's $\mathrm{V}=.213)$. 効果量の 值から, 生徒の満足度別にみた生徒の意見の反映 度には弱い関連性がみられ，人数の偏りが確認さ れた注5). 残差分析の結果, 運動部活動が「楽し い」と回答した生徒は,「苦しい」と回答した 生徒に比べ，生徒の意見が「とても反映されてい る」 $(Z= \pm 8.1, \mathrm{p}<.01)$, 「反映されている」 $(Z$ $= \pm 8.9, \mathrm{p}<.01 ）$ と回答した割合が有意に高かっ た. 反対に，「苦しい」と回答した生徒は，「あま り反映されていない」 $(Z= \pm 13.5, \mathrm{p}<.01)$ ，「ほ とんど反映されていない」 $(Z= \pm 15.7, \mathrm{p}<.01)$ と回答した割合が有意に高かった。この結果か ら，運動部活動の取り組みに抢いて自分たちの意 見が反映されている生徒は満足度が高いことが明 らかになった。

\section{4. まとめ}

本研究は, 中学・高等学校の運動部541部に所 属する8048名の生徒を対象に, 運動種目別及び 学校種別にみた運動部活動におけるチーム/個人 の目標設定, チームの勝利志向性, 生徒の意見の 反映度, 生徒の満足度それぞれに対する生徒の意 識の実態並びにそれらが運動部活動に対する生徒 の満足度に及ぼす影響を明らかにしようとした。 その結果, 以下の諸点が明らかになった。

\section{1）チーム/個人の目標設定, チームの勝利志 向性, 生徒の意見の反映度, 生徒の満足 度の実態}

(1)全体でみると, 生徒の多くは生徒中心に決定し たチーム目標があり，それをすべての生徒で共 有していた。 また，生徒の多くは個人目標があ り, 目標達成に向けて計画を立てて努力してい た. さらに, 生徒の多くはチームが勝利志向で あると捉えていた。加えて, 練習や試合におい て生徒の意見が反映されて抢り, 生徒の満足度 は高かった。

(2)運動種目別にみると, 集団種目の生徒の多くは 生徒中心で決定したチーム目標があり，それを すべての生徒が共有していた。 また彼らの多く は個人目標があり，その達成に向けて具体的な 計画があった．さらに彼らの多くは勝利志向 で, 練習や試合に抢いて生徒の意見が反映され て抢り, 生徒の満足度が高かった。一方で, 個 人種目の生徒の中にはチーム目標を指導者中心 で決定した生徒の割合が相対的に高かった。 た，彼らの中には楽しみ志向の生徒の割合も相 対的に高かった。ささらに，彼らはチーム/個人 の目標設定の割合が相対的に低かった.

(3)学校種別にみると, 高校生の多くは指導者とす べての生徒で決定したチーム目標があり, それ をすべての生徒が共有していた，また，彼らは 徹底して勝つ意識が強く, 練習や試合において 生徒の意見がより反映されていた，一方で，中 学生の多くはすべての生徒で決定したチーム目 
標があり，ある程度勝利中心で楽しむことを目 指す生徒の割合が相対的に高かった.

\section{2）チーム/個人の目標設定, チームの勝利志 向性, 生徒の意見の反映度それぞれが生 徒の満足度に及ぼす影響}

(1)個人の目標があり，その達成に向けて具体的な 計画を立て努力できている生徒の多くは満足度 が高かった。

(2)ある程度勝つことを中心に楽しむ生徒は相対的 に満足度が高かった一方で, 楽しみ中心に取り 組む生徒は相対的に満足度が低かった。

(3)自分たちの意見が反映されている生徒は相対的 に満足度が高かったが，逆に反映されていない 生徒は相対的に満足度が低かった.

(4)チーム目標は生徒中心で決定し，それをすべて の生徒が共有することが生徒の満足度に繋がる ことが示唆された.

\section{3） 今後の検討課題}

本研究では, 運動部活動に対する満足度を「楽 しさ」という 1 つの側面で捉えて分析した. 確 かに, 運動・スポーツに対する生徒の満足度を規 定する主な要因が「楽しさ」であることは違いな いが，それ以外にも多様な要因があると考えられ る. 実際に, 生徒の満足度を従属変数, それ以外 の測定項目を独立变数として重回帰分析を行った 結果, 生徒の満足度の決定係数は有意ではあった が比較的低い值であった．このことは, 運動部活 動に対する生徒の満足度を十分に説明できていな いことを意味して抢り，今回設定した以外の要因 が存在する可能性がある. その点は今後の検討課 題である.

\section{付記}

本研究は, 日本学術振興会科学研究費助成金 (課題番号 $15 \mathrm{~K} 01570$ 平成 27 年度 基盤研究 (C) 「生徒にとって望ましい運動部活動の指導の在り 方に関する研究（研究代表者 深見英一郎）」の配 分を受けて行われた.

\section{注}

注1）個人種目には，主な競技形式が個人競技である 陸上競技，バドミントン，テニス，ソフトテニ 又, 剣道, 柔道, 水泳, 卓球, 体操競技の他, 高 等学校のみ弓道, 空手道, ボクシング, レスリン グ, 山岳（全国高等学校体育連盟の登録名は「登 山」）が含まれる，一方で，集団種目には，主な競 技形式がチームで対戦する団体競技であるサッ カー, バスケットボール, バレーボール, ハンド ボール, ソフトボール，野球（中学校は軟式野球） の他, 高等学校のみラグビー（全国高等学校体育 連盟の登録名は「ラグビーフットボール」), 新体 操, ダンスが含まれる，このうち, 新体操とダン スに関しては，仲間と調和のとれた動きをしたり チームで1つのテーマ作品を表現したりする点 で，ここでは集団種目に分類した.

注2）調査用紙は無記名式であったが，得られたデー 夕は指導者にみられることを想定して回答された ものであるということを考慮すると，「楽しさ」や 「意見の反映度」などは肯定的な回答が多めに出て きた可能性がある。

注3）「満足度」とは学術的にも社会的にも多様な意味 を持つ概念であり，「楽しい」という評価と「満足 度」の高さは必ずしも完全に一致しない。しかし， 徳永・橋本 (1980) は, 運動部活動の生徒は, 運 動・スポーツに対する満足度を規定する主要因が 「楽しさ」であり，それに加えて「挑戦・達成」す ることであったと報告している．また石原（2012） は, 運動部活動を通して得られるもののうち, 何 が生徒の満足度に影響を与えているかを分析した 結果, 満足度と高い相関が 久られたのは「楽し さ」,「達成感」,「日常生活の充実感」であったと 報告している，さらに高橋（2001）は，体育授業 に対する総合的評価に対して最も強い規定力をも つのは「楽しさ」に代表される「意欲・関心」次 元であり，体育授業の成否を決定づける要因であ るといっても過言ではないと指摘している.

注4）残差分析の有意性判定は, 残差 $> \pm 1.65$ では $\mathrm{p}$ $<.10$, 残差 $> \pm 1.96$ では $\mathrm{p}<.05$, 残差 $> \pm 2.58$ で は $\mathrm{p}<.01$ となっている（田中・山際，2012）.

注5）運動種目/学校種別にみたチーム/個人の目標設 定, チームの勝利志向性, 生徒の意見の反映度, 生徒の満足度について, また生徒の満足度別に反 た個人の目標設定, チームの勝利志向性, 生徒の 意見の反映度についてそれぞれ効果量を測定し た. その結果, 効果量の値から「運動種目別にみ 
たチーム目標の有無（表 3 の一部）」と「生徒の満 足度別にみた生徒の意見の反映度（表11）」それぞ れの項目間に弱い関連性がみられ人数の偏りが確 認された一方で, それ以外の項目間における差異 は非常に小さな差であることが確認された.

注6）文部省（1997）の調査では，練習や試合におけ る生徒の意見の反映度について, 中学生の 75.4 $\%$, 高校生の $82.0 \%$ が（「とても反映されている」 を含めて）反映されていると回答していた.

注7）他方で, 表 8 においてチーム目標の有無は, 生 徒の満足度に有意な正の影響は認められなかった が, チーム目標の決定者, 共有状況及び生徒の属 性を独立変数として設定し（従属変数は生徒の満 足度), 再び重回帰分析 (カテゴリカル回帰) を行 った結果, 表 12 に示したように目標の決定者及び 目標の共有状況は生徒の満足度に影響を与えてい ることが明らかになった. 特に, 標準偏回帰係数 $\beta$ 值からチーム目標を共有しているかどうか（ $\beta$ $=.140, \mathrm{p}<.001)$, チーム目標を誰が決定したか $(\beta=.049, \mathrm{p}<.001)$ が生徒の満足度に対して重要 な影響を与えていることが示された。

表12 チーム目標の決定者, 共有状況及び生徒の属性 と生徒の満足度との関係

\begin{tabular}{ccc}
\hline & \multicolumn{1}{c}{ 標準偏回㷌係数 $(\beta)$} \\
\hline \multirow{2}{*}{ 目標 チーム目標の決定者 } & $.049^{* * *}$ \\
チーム目標の共有状況 & $.140^{* * *}$ \\
\hline \multirow{2}{*}{ 生徒の属性 学校種 } & $.058^{* * *}$ \\
& 運動種目 & .018 \\
\hline \multicolumn{2}{c}{$\mathrm{R}^{2}$} & $.032^{* * *}$ \\
\hline & $* * * \mathrm{p}<.001$
\end{tabular}

\section{文献}

朝日新聞（2016a）（フォーラム）中学校の部活動：1 活動時間. 2016年 4 月 17 日朝刊. 朝日新聞社.

朝日新聞 (2016b) (フォーラム) 中学校の部活動：2 教員. 2016年 4 月 24 日朝刊. 朝日新聞社.

Danish, S.J., Petitpas, A.J., and Hale, B.D. (1993) Life development intervention for athletes: Life skills through sports. The Counseling Psychologist, 21; 352-385.

藤田雅文・吉田哲也（2010）中学校運動部顧問の管理 行動に関する研究一競技経験との関連性一. 鳴門教 育大学研究紀要, 25: 347-352.
石原 剛（2012）運動部活動がもたらす効用の要因分 析一愛媛県の高等学校を対象として一. 2012年 2 月 政策研究大学院大学 教育政策プログラム 修士論文. http: / / www3.grips.ac.jp / education / wp / wpcontent/uploads / 2014/04/201101.pdf（参照日2015 年12月30日).

伊藤雅充（2013）より良い運動部活動のコーチングを 目指して. SYNAPSE, 25: 24-27.

Jean C. and Wade G. (2009) An integrative definition of coaching effectiveness and expertise. International journal of sports science \& coaching, 4(3): 307-323. 勝田 隆 (2000) 知的コーチングのすすめ一頂点をめ ざす競技者育成の鍵. 大修館書店.

倉藤利早 ·田島 誠・米谷正造 (2011) 指導者のリー ダーシップのタイプが選手の自主性に及ぼす影響. 川崎医療福祉学会誌, 20(2): 457-460.

桑野友裕 - 小原達朗 ·笹山龍太郎 (2014) 生徒指導の 内容を踏をえた運動部活動指導の研究一自己指導能 力を育む運動部活動指導一. 長崎大学教育学部 教育 実践総合センター紀要, 13: 221-230.

教育新聞 (2011) 社説「中学校の部活動 新学習指導 要領による見直しを」2011年 6 月 23 日号. 教育新聞 社.

丸山仁志 (2013) 中学校部活動の自主性に関する研究 一運動部における顧問教師と生徒の意識に着目して 一. 2013年度 びわこ成蹊スポーツ大学卒業研究抄録 集. p. 103.

文部省（1997）平成 9 年12月 運動部活動の在り方に 関する調査研究報告（中学生・高校生のスポーツ活 動に関する調査研究協力者会議). http://www.mext. go.jp/b_menu/shingi/chousa/sports / 001/toushin / $971201 . h t m （$ 参照日2015年12月30日）

文部科学省（2002）運動部活動の実態に関する調査 (平成 13 年). http: // www.mext.go.jp / b_menu / shingi / chukyo / chukyo5 / 009 / gijiroku / __icsFiles / afieldfile/2011/09/14/1310757_04.pdf（参照日2016 年 5 月 28 日）

文部科学省（2012）部活動の意義と留意点等. スポー ツ青少年局企画体育課編, 中学校学習指導要領解説 保健体育編. 東山書房, pp. 170-172.

文部科学省（2014）運動部活動の在り方に関する調査 研究報告書〜一人一人の生徒が輝く運動部活動を目 指して〜。平成 25 年 5 月 27 日 運動部活動の在り方 に関する調査研究協力者会議. http://www.mext. go.jp/a_menu/sports/jyujitsu/__icsFiles / afieldfile / 2013/05/27/1335529_1.pdf (参照日2016年 3 月31日) 文部科学省（2015）地域スポーツに関する基礎データ 
集（平成 27 年 4 月）. http: // www.mext.go.jp / b _ menu/shingi/chousa/sports/025/shiryo/__icsFiles/ afieldfile/2015/05/01/1357467_4.pdf（参照日 2016 年 5 月 28 日)

中澤篤史 (2015) 運動部活動の戦後と現在 なぜスポー ツは学校体育に結び付けられるのか. 青弓社.

西島 央 (2006) 部活動一その現状とこれからのあり

方. 学事出版, pp. 12-16.

西島 央 (2013)「べき」や「はず」の学校教育にとら われない部活動をめざして. 体育科教育, 61(3): 1417.

岡沢祥訓（2001）メンタルを考えよう一卓球に学ぶス ポーツ心理学. 卓球王国.

佐藤正伸・長堂益丈 (1995) 競技者の競技意欲に対す る指導者の影響. 陸上競技研究，12: 34-43.

佐藤 豊 (2013) 学校運動部活動の教育的意義を再考 する. 現代スポーツ評論, 28: 60-74.

制野俊弘（2013）自治集団活動としての運動部活動を 構想する. 体育科教育, 61(3): 34-37.

田中 敏・山際勇一郎 (2012) 新訂ユーザーのための
教育 · 心理統計と実験計画法. 教育出版, p. 263. 高橋健夫（2001）体育授業を観察評価する. 大修館書 店, p. 13 .

徳永幹雄・橋本公雄（1980）体育授業の「運動の楽し さ」に関する因子分析的研究. 健康科学, 2: 75-90.

友添秀則 (2013) 学校運動部の課題とは何か一混迷 する学校運動部をめぐって. 現代スポーツ評論, 28 : 8-18.

鶴山博之（2010）高校陸上競技部のリーダーシップに 関する研究. 富山国際大学子ども育成学部紀要, 1 : $53-62$.

上野耕平 (2006) 運動部活動への参加による目標設定 スキルの獲得と時間的展望の関係. 体育学研究, 51 (1) : 49-60.

$\left(\begin{array}{l}2016 \text { 年 } 1 \text { 月 } 5 \text { 日受付 } \\ 2016 \text { 年 } 7 \text { 月 } 19 \text { 日受理 }\end{array}\right)$

Advance Publication by J-STAGE

Published online 2016/8/19 